\title{
HUBUNGAN SELF-EFFICACY DAN KOMPETENSI PROFESIONAL DENGAN KINERJA GURU PADA SEKOLAH MENENGAH ATAS DI SUB RAYON 11 PARUNG KABUPATEN BOGOR
}

\author{
Nur Isyanto \\ Sekolah Tinggi Agama Islam Nurul Iman Parung Bogor \\ Jl. Nurul Iman No. 01 RT/RW. 01/01, Ds. Waru Jaya, Parung, Bogor \\ Email: mnoer09@gmail.com
}

\begin{abstract}
This research aims to identify and test empirical data related to self-efficacy relationship and professional's competence with teacher's performance separately and simultaneously. Results in this research, there is a positive and significant relationship between self efficacy and professional's competence together with teacher's performance in sub rayon 11 parung kabupaten bogor. There is a positive and significant relationship between self efficacy and teacher's performance with a coefficient of correlation of 0.659 point and coefficient of determination of 0.435 point which gives effect with teacher performance of $43.5 \%$ and the remaining $56.5 \%$ is determined by other factors. There is a positive and significant relationship between professional's competence with teacher's performance with coefficient of correlation 0.659 point and coefficient of determination of 0.435 point which gives effect with teacher performance of $43.5 \%$ and the rest is $56.5 \%$ determined by other factors. There is a positive and significant correlation between self efficacy and professional's competence together with teacher's performance with coefficient of correlation $=$ 0,662 point and coefficient of determination equal to 0,438 point which give effect simultaneously with teacher's performance equal to $43,8 \%$ and the rest is $56,2 \%$ is determined by other factors. The results coefficient of regression that self efficacy and professional's competence together given affected for teacher's performance in sub rayon 11 parung kabupaten bogor.
\end{abstract}

Keywords: Self-Efficacy, Professional's Competence, Teacher's Performance.

\begin{abstract}
Abstrak
Penelitian ini bertujuan untuk mengetahui dan menguji data-data empirik terkait hubungan efikasi diri (self-efficacy) dan kompetensi profesional dengan kinerja guru secara terpisah maupun simultan. Hasil penelitian ini menunjukkan bahwa dari hasil perhitungan koefisien regresi menunjukkan terdapat hubungan positif antara efikasi diri (self-efficacy) dan kompetensi profesional dengan kinerja guru di sub rayon 11 parung kabupaten bogor. Hasil analisis uji koefisien kolerasi menunjukkan bahwa variabel efikasi diri (self-efficacy) memiliki hubungan yang positif dan signifikan dengan variabel kinerja guru, dari hasil analisis koefisien determinasi menunjukan bahwa variabel efikasi diri (self-efficacy) dengan variabel kinerja guru berpengaruh sebesar $43,5 \%$ dan sisanya $56,5 \%$ ditentukan oleh faktor lainnya. Hasil analisis uji koefisien kolerasi untuk variabel kompetensi profesional memiliki hubungan yang positif dan signifikan dengan variabel kinerja guru, dari hasil analisis koefisien determinasi menunjukan bahwa variabel kompetensi profesional dengan
\end{abstract}


Nur Isyanto

variabel kinerja guru berpengaruh sebesar 43,5\% dan sisanya 56,5\% ditentukan oleh faktor lainnya. Hasil analisis uji koefisien kolerasi untuk variabel efikasi diri (selfefficacy) dan kompetensi profesional memiliki hubungan yang positif dan signifikan dengan variabel kinerja guru, dari hasil analisis koefisien determinasi menunjukan bahwa variabel efikasi diri (self-efficacy) dan variabel kompetensi profesional dengan variabel kinerja guru yang memberi berpengaruh bersama- sama sebesar 43,8\% dan sisanya 56,2 \% ditentukan oleh faktor lainnya. Dari hasil uji regresi menunjukan bahwa variabel efikasi diri (self-efficacy) dan variabel kompetensi profesional memberi berpengaruh terhadap variabel kinerja guru di sub rayon 11 Parung Kabupaten Bogor.

Kata Kunci: Self-Efficacy, Kompetensi Profesional, Kinerja Guru

\section{A. Pendahuluan}

Pendidikan Nasional berfungsi mengembangkan kemampuan dan membentuk watak serta peradaban bangsa yang bermartabat dalam rangka mencerdaskan kehidupan bangsa, bertujuan untuk berkembangnya potensi peserta didik agar menjadi manusia yang beriman dan bertakwa kepada Tuhan Yang Maha Esa, berakhlak mulia, sehat, berilmu, cakap, kreatif, mandiri, dan menjadi warga negara yang demokratis serta bertanggung jawab. ${ }^{1}$

Guru dituntut memiliki kinerja yang mampu memberikan dan merealisasikan harapan dan keinginan semua pihak terutama masyarakat umum yang telah mempercayai sekolah dan guru dalam membina anak didik. Dalam meraih mutu pendidikan yang baik sangat dipengaruhi oleh kinerja guru dalam melaksanakan tugasnya sehingga kinerja guru menjadi tuntutan penting untuk mencapai keberhasilan pendidikan. Secara umum mutu pendidikan yang baik menjadi tolak ukur bagi keberhasilan kinerja yang ditunjukkan guru. Namun sungguh disayangkan, kualitas guru di Indonesia dinilai masih memprihatinkan. Hal tersebut dapat dilihat dari tingkat kompetensi guru saat ini.

Direktur Jenderal Guru dan Tenaga Kependidikan, Kementerian Pendidikan dan Kebudayaan Sumarna Surapranata mengatakan, kompetensi guru salah satunya dapat dilihat dari gambaran hasil uji kompetensi guru (UKG). Dia mengatakan sangat sedikit guru yang memperoleh nilai yang baik dalam UKG. Sumarna mengungkapkan ada guru yang hanya mampu menjawab satu dari 40 soal."Ini sebuah fakta. Ada guru fisika yang berhasil menjawab satu dari 40 soal yang ada. Ini terjadi di beberapa mata pelajaran", kata dia. Ironinya dari hasil

${ }^{1}$ Dewan Perwakilan Rakyat Republik Indonesia, Undang-Undang RI Nomor 20 Tahun 2003 tentang Sisdiknas. Bandung: Citra Umbara, t.th, h. 72.

100 | Al Ashriyyah, Vol.5 No.1 Mei 2019 
uji kompetensi tersebut ditemukan skor guru bergelar doktor kalah dengan yang hanya lulusan SMA. Padahal guru ini tetap menerima tunjangan profesi. ${ }^{2}$

Semenjak penyelenggaraan program sertifikasi guru selalu terbebani oleh berbagai birokrasi aturan administratif yang terkait dengan kepentingan proyek sertifikasi untuk mendapatkan tunjangan profesi guru. Guru di dalam skema proyek sertifikasi seolah diletakkan sebagai "kuli" yang melakukan "kerja lembur" untuk mendapatkan tunjangan profesi sebesar satu kali gaji pokok. Beban administrasi yang diterima oleh guru, konon didasari oleh logika kebijakan pemerintah yang ingin mengatur guru dan membuat database tentang guru demi kepentingan mengejar target profesionalisme guru.

Tahun 2012 muncul logika "mekanistik" kebijakan pemerintah pusat melalui terbitnya Surat Keputusan Bersama (SKB) 5 menteri. Di mana dalam SKB 5 menteri guru diwajibkan memenuhi limit alokasi jam mengajar (tatap muka) di ruang kelas minimal 24 jam dan maksimal 40 jam perminggu. Terbitnya SKB 5 menteri yang memaksa guru memenuhi batas jam mengajar di ruang kelas minimal 24 jam menciptakan realitas yang "buruk" dalam dunia pendidikan, khususnya yang dialami para guru. ${ }^{3}$

Analisa mendalam yang mengupas dinamika guru sertifikasi penuhi syarat administrasi membuktikan bahwa sesungguhnya guru terbebani oleh persoalan administrasi yang rumit yang justru mereduksi hakikat guru sebagai penyampai ilmu dan teladan dalam sikap serta pemikiran. Jam mengajar guru menjadi patokan ukuran profesionalisme guru dan guru dipaksa memenuhi standar kewajiban administratif yang tidak selaras dengan mandat pedagogis guru. ${ }^{4}$

Hasil penelitian yang disampaikan oleh MaPPI FHUI $^{5}$ saat diskusi media terkait Hari Anti Kekerasan Terhadap Perempuan pada

\footnotetext{
${ }^{2}$ https://nasional.sindonews.com/read/1052998/15/memprihatinkan-ada-guruhanya-bisa-jawab-satu-soal-ujian-1444794753, diakses pada tanggal 01 Nopember 2017 pukul 17.51 WIB.

${ }^{3}$ http://dok.joglosemar.co/baca/2015/11/17/guru-bukan-kuli.html, diakses pada tanggal 01 Nopember 2017 pukul 18.03 WIB.

${ }^{4}$ http://dok.joglosemar.co/baca/2015/11/17/guru-bukan-kuli.html, diakses pada tanggal 01 Nopember 2017 pukul 18.03 WIB.

5 MaPPI FHUI kepanjangan dari Masyarakat Pemantau Peradilan Indonesia. MaPPI FHUI adalah lembaga otonom yang berada di bawah Fakultas Hukum Universitas Indonesia dan bergerak dalam bidang Penelitian dan Advokasi Peradilan. Lembaga yang bersifat Indenpenden dan Profesional. Lihat dalam
} 
Jumat, 24 November 2017. Dalam diskusi tersebut, Bestha Imatsan Ashila selaku peneliti di MaPPI FHUI mengatakan bahwa tahun 2017 ini kekerasan seksual paling banyak dilakukan oleh guru. Jika pada 2016 pelaku paling banyak dari relasi orang yang dikenal korban, seperti orang tua kandung atau tiri, pacar, saudara, kerabat, teman, tetangga, rekan kerja, guru, atau atasan. Namun, dari kelompok orang yang dikenal ini, di 2017, guru menjadi pelaku. ${ }^{6}$

Disinyalir demi nama baik, prestasi dan gengsi daerah dan sekolah yang dipertaruhkan, berdasarkan acara Reportase Investigasi Trans TV, praktek kecurangan dalam ujian nasional ternyata diketahui oleh kepala sekolah. Sekolah dengan sengaja membeli kunci jawaban dari oknum dinas pendidikan yang kemudian diserahkan kepada guruguru yang menjadi tim sukses ujian. Tim sukses ini yang akan memeriksa ulang jawabannya kemudian baru disebarkan ke beberapa siswa yang telah ditunjuk untuk membocorkan ke teman- teman yang lainnya. ${ }^{7}$ Bahkan kecurangan ini berulang terus di setiap tahunnya dengan beragam modus dari tahun 2013- 2016, sebagaimana yang dicatat oleh portal berita okezone. ${ }^{8}$

Berdasarkan latar belakang tersebut di atas maka peneliti mencoba dan tertarik untuk melakukan penelitian tentang hubungan antara self-efficacy dan kompetensi profesional dengan kinerja guru Sekolah Menengah Atas di Sub Rayon 11 Parung, Bogor.

\section{B. Kajian Teori}

Kinerja Guru

Menurut Brumbach dalam Amstrong bahwa kinerja dapat diartikan sebagai perilaku dan hasil, yang mana perilaku berasal dari pelaku yang mengubah kinerja itu sendiri dari hal- hal yang abstrak menjadi tindakan. ${ }^{9}$ Ivancevich, Konopaske, dan Matheson menyatakan

http://mappifhui.org/sejarah/, diakses pada tanggal 12 Agustus 2018 pukul 04.46 WIB.

6 http://pepnews.com/2017/11/27/guru-cabul-pelaku-kekerasan-seksual-danhari-guru-nasional/ diakses pada tanggal 01 Nopember 2017 pukul 17.23 WIB.

${ }^{7}$ Reportase Investigasi, Sekolah Ajari Aku Curang, Trans TV: Sabtu: 27 April 2013, http://www.youtube.com/watch?v=EXyDUDcDuy4. diakses pada tanggal 01 Nopember 2017 pukul 17.33 WIB.

$8 \quad$ https://news.okezone.com/read/2016/04/09/65/1358480/beragamkecurangan-un-terulang-setiap-tahun, diakses pada tanggal 01 Nopember 2017 pukul 17.43 WIB.

${ }^{9}$ Michael Amstrong, Performance Management Key Strategies and Practical Guidelines. London: British Library, 2006, h. 7. 
bahwa kinerja adalah seperangkat perilaku hubungan kerja karyawan yang dirancang untuk mencapai tujuan organisasi. ${ }^{10}$

Kinerja guru adalah seperangkat perilaku nyata yang ditunjukkan oleh seorang guru pada peserta didiknya. Perilaku nyata tersebut meliputi merencanakan, mengelola pelaksanaan, menilai proses hasil, mendiagnosis kesulitan belajar dan merevisi program pembelajaran. ${ }^{11}$ kinerja yang berkaitan dengan profesi guru sebagai seperangkat perilaku nyata yang ditunjukkan oleh seorang guru pada saat memberikan pelajaran kepada peserta didiknya. ${ }^{12}$ Kinerja guru merupakan hasil kerja yang dicapai guru di sekolah dalam rangka mencapai tujuan sekolah. ${ }^{13}$ Sedangkan menurut Supardi kinerja guru merupakan kemampuan seorang guru dalam melaksanakan tugas pembelajaran di madrasah dan bertanggung jawab atas peserta didik di bawah bimbingannya dengan meningkatkan prestasi belajar peserta didik. $^{14}$

Santrock mengemukakan akan adanya pengaruh antara kinerja, self-efficacy dan kemampuan. Santrock mengatakan bahwa self-efficacy bukanlah merupakan satu-satunya faktor yang mempunyai pengaruh kuat pada prestasi. Self-efficacy yang tinggi tidak akan menghasilkan kinerja yang kompeten bila pengetahuan dan keterampilan yang dibutuhkan kurang. ${ }^{15}$ Bahkan Gibson et al mengemukakan bahwa seseorang yang memiliki self-efficacy yang tinggi merasa percaya diri pada kemampuan dan kinerja tugas mereka. ${ }^{16}$

Self-Efficacy

Self-efficacy adalah keyakinan seseorang tentang kemungkinan berhasil dalam menyelesaikan tugas tertentu. ${ }^{17}$ self-efficacy adalah

${ }^{10}$ John M. Ivanovich, Robert Konopaske dan Michael T. Matheson, Organizational Behavior and Management. New York: McGraw-Hill, 2014, h. 172.

11 Soediyarto, Rekrutmen, Pendidikan dan Penempatan serta Pemahaman Guru untuk Menunjang Pendidikan untuk Masyarakat Indonesia Baru, Jakarta: Grasindo, 2012, h. 78.

12 Anwar Prabu Mangkunegara, Perilaku dan Budaya Organisasi, Bandung: Refika Aditama, 2012, h. 22.

${ }^{13}$ Donni Priansa, Kinerja dan Profesionalisme Guru, Bandung: Alfabeta, 2014, h. 79.

${ }^{14}$ Supardi, Kinerja Guru, Jakarta: PT Raja Grafindo Persada, 2014, h. 54.

15 John W. Santrock, Educational Psychology. New York: Mc Graw-Hill, 2011, h. 245-246.

${ }^{16}$ James L. Gibson, et al., Organization: Behavior, Structure, Processes. New York: Mc Graw-Hill, 2009, h. 209.

${ }^{17}$ John R. Schermerhorn, Jr, et al., Organizational Behavior. USA: John Wiley \& Sons, Inc, 2010, h. 29. 
keyakinan bahwa seseorang memiliki kemampuan yang dibutuhkan untuk melaksanakan suatu pekerjaan dengan sukses. ${ }^{18}$ Sementara itu menurut Bandura yang dikutip Santrock mengemukakan bahwa Selfefficacy adalah keyakinan bahwa seseorang dapat menguasai situasi dan memproduksi hasil yang positif. Self-efficacy memiliki pengaruh yang kuat terhadap perilaku. ${ }^{19}$ Robbins berpendapat Self-efficacy adalah keyakinan seseorang bahwa ia mampu menjalankan sebuah tugas. ${ }^{20}$ Lebih jauh Robbins mengemukakan bahwa semakin tinggi selfefficacy yang kamu miliki, semakin percaya diri di dalam kemampuan kamu untuk dapat keberhasilan. ${ }^{21}$ Kreitner dan Kinicki menjelaskan bahwa self-efficacy merupakan keyakinan diri akan peluang keberhasilannya dalam menyelesaikan tugas tertentu, serta percaya pada kemampuannya untuk dapat menyelesaikan tugas.

Kinerja dipengaruhi oleh efikasi diri (self-efficacy) sebagaimana yang dikemukakan Robbins bahwa para manajer menetapkan tujuan yang sulit bagi para karyawannya, ini menyebabkan mereka memiliki tingkat self-efficacy yang lebih tinggi dan juga membawa mereka untuk menetapkan tujuan yang lebih tinggi bagi kinerja mereka sendiri. ${ }^{22}$ Kompetensi Profesional

Kompetensi profesional dalam arti guru harus menguasai keilmuan bidang studi yang diajarkannya, serta mampu melakukan kajian kritis dan pendalaman isi bidang studi. ${ }^{23}$ Kompetensi profesional merupakan penguasaan materi pembelajaran secara luas dan mendalam, yang mencakup penguasaan materi kurikulum mata pelajaran di sekolah dan subtansi keilmuan yang menaungi materinya, serta penguasaan terhadap struktur dan metodelogi keilmuanya. ${ }^{24}$

18 Jason A. Colquitt, Jeffrey A. Lepine dan Michael J. Wesson, Organizational Behavior Improving Performance and Commitment in Workplace. New York: McGraw-Hill, 2013, h. 170.

${ }^{19}$ John W. Santrock, Educational Psychology...., h. 236.

${ }^{20}$ Stephen P. Robbins dan Timothy A. Judge, Organizational Behavior. New Jersey: Pearson Prentice Hall, 2017, h. 258.

${ }^{21}$ Stephen P. Robbins dan Timothy A. Judge, Organizational Behavior, ..., h. 258.

${ }^{22}$ Stephen P. Robbins dan Timothy A. Judge, Organizational Behavior, ..., h. 258.

${ }^{23}$ Moh. Roqib, Ilmu Pendidikan Islam: Pengembangan Pendidikan Intergratif di Sekolah, Keluarga, Masyarakat, Jogyakarta: PT LKIS Printing cemerlang, 2009, h. 53.

24 Farida Samariya, Sertifikasi Guru; Apa, Mengapa, dan Bagaimana?, Bandung: Yrama Widya, 2008, h. 21. 
Kompetensi profesional merupakan kemampuan penguasaan materi pembelajaran secara meluas dan mendalam yaitu meliputi konsep, struktur, dan metode keilmuan teknologi/ seni yang menaungi/ koheren dengan materi ajar yang ada dalam kurikulum sekolah, hubungan konsep antar mata pelajaran terkait, penerapan konsep- konsep keilmuan dalam kehidupan sehari- hari dan kompetensi secara profesional dalam konteks global dengan tetap melestarikan nilai dan budaya nasional. ${ }^{25}$ Sedangkan pengertian kompetensi profesional guru dalam standar pendidikan, penjelasan pasal 28 ayat 3 butir c dikemukakan bahwa kompetensi profesional adalah kemampuan penguasaan materi pembelajaran secara luas dan mendalam yang memungkinkan peserta didik memenuhi standar kompetensi yang ditetapkan dalam standar nasional pendidikan. ${ }^{26}$

Colquitt berpendapat bahwa orang yang memiliki kemampuan umum kognitif lebih tinggi cenderung lebih baik dalam mempelajari sesuatu dan membuat keputusan. Kemampuan umum kognitif mempunyai hubungan positif yang kuat dengan kinerja kerja terutama disebabkan pengaruhnya pada kinerja tugas. ${ }^{27}$ Kemudian Woods dan West berpendapat bahwa orang dengan kemampuan tingkat yang lebih tinggi cenderung berkinerja lebih baik di tempat kerja. Orang dengan kemampuan tingkat yang lebih tinggi mampu untuk memperoleh pengetahuan lebih banyak tentang pekerjaan mereka dan memperolehnya dengan cepat. Dalam pekerjaan yang lebih kompleks, lebih banyak pengetahuan yang harus diperoleh, dan itu semakin besar kemungkinan bahwa penguasaan pengetahuan akan terus menjadi penting untuk kinerja. ${ }^{28}$

Berdasarkan analisis hubungan antar variabel sebagaimana diuraikan di atas dapat di gambarkan menjadi kerangka pemikiran sebagai berikut;

${ }^{25}$ Achjar Chalil, Pembelajaran Berbasis Fitrah, Jakarta: PT.Balai Pustaka, 2008, h. 69.

${ }^{26}$ Jamil Suprihatiningrum, Guru Profesional Pedoman Kinerja, Kualifikasi \& Kompetensi Guru, Yogyakarta: Arruz Media, 2013, h. 115.

${ }^{27}$ Jason A. Colquitt, et al, Organizational Behavior Improving, ..., h. 341.

28 Stephen A. Woods and Michael A. West, The Psychology of Work Organizations, Hamispire: Cengage Learning EMEA, 2010, h. 84. 


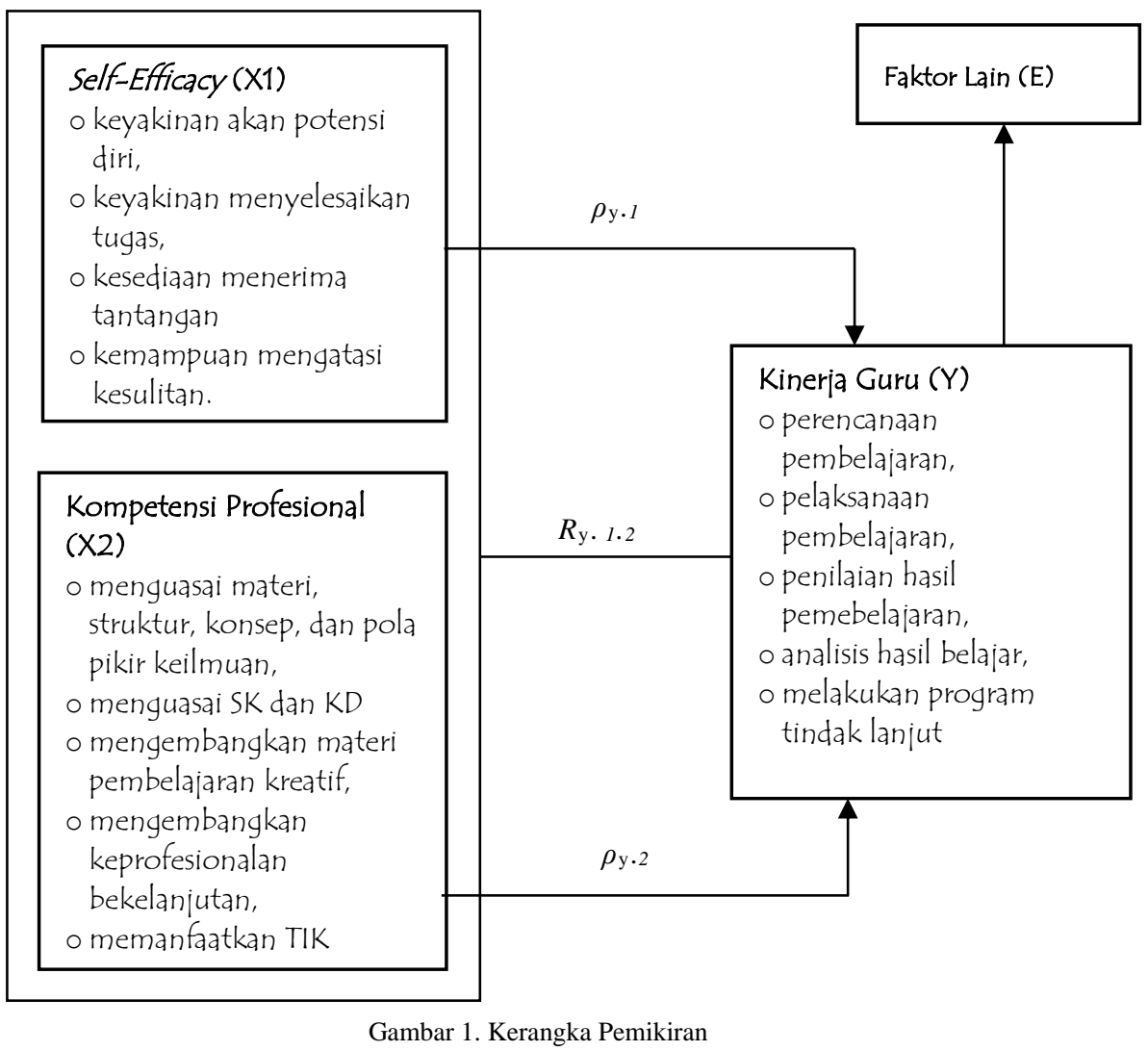

C. Metode

Penelitian ini merupakan penelitian lapangan bersifat kuantitatif dan dengan jenis penelitian korelasional. Penelitian lapangan merupakan suatu penelitian untuk memperoleh data- data yang sebenarnya terjadi di lapangan. Penelitian regresional adalah suatu penelitian yang bertujuan menyelidiki sejauh mana variasi pada suatu variabel berkaitan dengan variasi variabel lain. ${ }^{29}$ Dalam hal ini, mencari data ada-tidaknya hubungan antara vaiabel dan apabila ada seberapa eratnya hubungan serta berarti atau tidaknya hubungan itu. ${ }^{30}$ Sedangkan bersifat kuantitatif berarti menekankan analisa pada data numerikal (angka) yang diperoleh dengan metode statistik. ${ }^{31}$ Metode penelitian yang akan digunakan dalam penelitian ini adalah menggunakan pendekatan kuantitatif, metode survey dengan teknik penelitian

${ }^{29}$ Saifudin Azwar, Metode Penelitian, Yogyakarta: Pustaka Pelajar, 2011, h. 8.

30 Suharsimi Arikunto, Prosedur Penelitian: Suatu Pendekatan Praktek, Jakarta: PT Rineka Cipta, 2012, h. 238.

${ }^{31}$ Saifudin Azwar, Metode Penelitian, Yogyakarta: Pustaka Pelajar, 2011, h. 5 
deskriptif korelasional. Peneliti dalam hal ini menggunakan instrumen tes dengan sejumlah pernyataan yang digunakan untuk mengetahui informasi yang diinginkan dari subjek penelitian. Instrumen data tersebut berupa angket dan wawancara.

Variabel meliputi dua variabel bebas yaitu self-efficacy (X1), kompetensi profesional (X2), dan satu variabel terikat yaitu kinerja guru (Y). definisi operasional dari variabel- variabel tersebut adalah; kinerja guru adalah serangkaian perilaku nyata yang dihasilkan oleh seorang guru baik secara kuantitas maupun kualitas untuk mencapai hasil pembelajaran yang maksimal yang diukur menggunakan instrumen penilaian yang terkait dengan indikator: (1) perencanaan pembelajaran, (2) pelaksanaan pembelajaran, (3) penilaian hasil pemebelajaran, (4) analisis hasil belajar, dan (5) melakukan program tindak lanjut. Self-efficacy adalah Penilaian keyakinan guru akan kemungkinan keberhasilannya dalam menyelesaikan tugas yang diembannya untuk mencapai suatu hasil yang diharapkan diukur menggunakan instrumen penilaian yang terkait dengan indikator: (1) keyakinan akan potensi diri, (2) keyakinan menyelesaikan tugas, (3) kesediaan menerima tantangan dan (4) kemampuan mengatasi kesulitan. kompetensi profesional guru adalah kemampuan yang dimiliki guru dalam menguasai mata pelajaran yang diampu dan cara mengajarkanya kepada siswa dengan melihat pada; (1) menguasai materi, struktur, konsep, dan pola pikir keilmuan yang mendukung mata pelajaran yang diampu, (2) menguasai standar kompetensi dan kompetensi dasar mata pelajaran yang diampu, (3) mengembangkan materi pembelajaran yang diampu secara kreatif, (4) mengembangkan keprofesionalan secara bekelanjutan dengan melakukan tindakan reflektif, dan (5) memanfaatkan teknologi informasi dan komunikasi untuk mengembangkan diri.

Unit analisis penelitian ini adalah guru. populasi target dalam penelitian ini adalah seluruh guru Sekolah Menengah Atas yang berada di Sub Rayon 11 Parung Kabupaten Bogor, sedangkan populasi terjangkau dalam penelitian ini adalah seluruh guru pada sekolah yang telah ditentukan terdiri dari SMA School of Universe, SMA Islam AlMukhlisin, SMA Riyadhlul Jannah dan SMA Al-Ashriyyah Nurul Iman. Sampel dalam penelitian ini adalah sebanyak 104 guru yang 
diambil secara acak (proporsional random sampling). Besaran sampel menggunakan rumus Slovin, ${ }^{32}$ yaitu sebagai berikut:

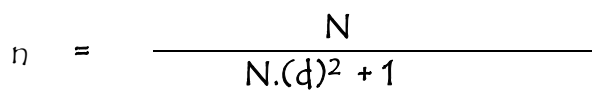

$$
\begin{aligned}
\text { Keterangan: } & \\
\mathrm{n} & : \text { Jumlah Sampel } \\
\mathrm{N} & : \text { Jumlah Populasi } \\
\mathrm{d} & : \text { Margin error }=5 \% \\
1 & : \text { Konstanta }
\end{aligned}
$$

Terdapat dua macam analisis/ statistik yang dapat digunakan untuk menganalisis data dalam penelitian, yaitu analisis/ statistik deskriptif dan analisis/ statistik inferensial. Analisis/ statistik inferensial terdiri dari dua bagian yaitu statistik parametrik dan statistik nonparametrik. ${ }^{33}$

Analisis deskriptif adalah analisis yang digunakan untuk menggambarkan tentang ringkasan data- data penelitian yang telah terkumpul sebagaimana adanya tanpa bermaksud membuat kesimpulan yang berlaku umum atau generalisasi. Analisis deskriptif ini digunakan untuk mengetahui dan menyajikan jumlah responden $(N)$, harga ratarata (mean), rata-rata kesalahan standar (Standard Error of Mean), median, modus (mode), simpang baku (standard deviation), varian (variance), rentang (range), skor terendah (minimum scor), skor tertinggi (maximum scor), dan distribusi frekuensi yang disertai grafik histogram dari kelima variabel tersebut.

Analisis Inferensial sering juga disebut analisis induktif atau analisis probabilitas adalah teknik analisis yang digunakan untuk menganalisis data sampel dan hasilnya di berlakukan untuk populasi. ${ }^{34}$ Pengujian hipotesis dengan analisis inferensial yang menggunakan statistic parametric memerlukan terpenuhnya banyak asumsi sebagai persyaratan analaisis. ${ }^{35}$ Asumsi yang utama adalah data yang akan dianalisis harus berdistribusi normal, data dua kelompok atau lebih yang diuji harus homogen, dan dalam uji regresi harus terpenuhi asumsi linieritas. Korelasi parsial untuk dua variabel yang dikontrol oleh sebuah variabel lain, serta analisis regresi dan korelasi ganda digunakan

${ }^{32}$ Husein Umar, Metodologi Penelitian untuk Skripsi dan Tesis Bisnis, Jakarta: Grafindo Persada, 2008, h. 78.

${ }^{33}$ Sugiyono, Metode Penelitian Pendidikan Pendekatan Kualitatif, Kuantitatif, dan $R$ \& D, Bandung: Alfabet, 2010, h. 207.

${ }^{34}$ Sugiyono, Metode Penelitian Pendidikan Pendekatan, ..., h. 209.

${ }^{35}$ Sugiyono, Metode Penelitian Pendidikan Pendekatan, ..., h. 210. 
untuk menganalisis tiga variabel secara bersama- sama. Uji persyaratan analisis adalah uji normalitas dengan menggunakan galat taksiran uji Lilliefors dan uji homogenitas dengan menggunakan uji Barlett. ${ }^{36}$

\section{A. HASIL}

Adapun rekapitulasi uji validitas dan reliabilitas disajikan pada tabel 1. dan tabel 2. berikut ini;

Tabel 1. Rekapitulasi Hasil Uji Validitas

\begin{tabular}{llccc}
\hline No & & \multicolumn{3}{c}{ Vatiabel Soal } \\
\cline { 3 - 5 } 1 & Kineria Guru & Jumlah & Valid & Tdk Valid \\
2 & Self-Efficacy & 40 & 36 & 4 \\
3 & Kompetensi Profesional & 40 & 34 & 6 \\
\hline
\end{tabular}

Tabel 2. Rekapitulasi Hasil Uji Reliabilitas

\begin{tabular}{clcl}
\hline No & \multicolumn{1}{c}{ Variabel } & Nilai & Ket \\
\hline 1 & Kineria Guru & 0,8678 & Reliabel \\
2 & Self-Efficacy & 0,9493 & Reliabel \\
3 & Kompetensi Profesional & 0,8736 & Reliabel \\
\hline
\end{tabular}

Hasil pengujian data deskriptif menunjukkan bahwa ketiga variabel yang diteliti memiliki tingkat perkembangan variabel berada pada taraf tinggi dan yang tertinggi ialah variabel kompetensi profesional sebesar $80,385 \%$. Distribusi data bersifat normal dan homogen, tidak terjadi multikolinieritas maupun heteros-kedastisitas.

Tabel 3. Rekapitulasi Hasil Analisis Uji Koefesien Korelasi

\begin{tabular}{|c|c|c|c|c|}
\hline Koefisien Korelasi & $n$ & $\boldsymbol{\rho}_{\mathrm{y}} / R_{\mathrm{y}}$ & $\alpha$ & Keterangan \\
\hline$Y \operatorname{atas} X_{1}$ & 104 & 0,659 & 0,01 & Terdapat Pengaruh \\
\hline$Y \operatorname{atas} X_{2}\left(\boldsymbol{\rho}_{y \cdot 2)}\right.$ & 104 & 0,659 & 0,01 & Terdapat Pengaruh \\
\hline$Y \operatorname{atas} X_{1} d a n X_{2}\left(R_{Y \cdot 1 \cdot 2)}\right.$ & 104 & 0,662 & 0,01 & Terdapat Pengaruh \\
\hline
\end{tabular}

Berdasarkan tabel 3. tentang pengujian hipotesis $\rho_{\mathrm{y} \cdot 1}$ di atas, menunjukkan bahwa pada tingkat kepercayaan $99 \%(\alpha=0,01)$ diperoleh koefisien korelasi Pearson correlation $\left(\rho_{\mathrm{y} \cdot 1}\right)$ adalah 0,659 . Pengujian hipotesis $\rho_{\mathrm{y} \cdot 2}$ diperoleh koefisien korelasi $\left(\rho_{\mathrm{y} \cdot 2)}\right)$ adalah 0,659 .

${ }^{36}$ Sudjana, Metoda Statistika, Bandung : Tarsito, 2005, h. 466. 
Pengujian hipotesis $R_{\mathrm{y} \cdot 1.2}$ diperoleh koefisien korelasi ganda (hipotesis $R_{\mathrm{y} .1 .2}$ ) adalah 0,662. Dengan demikian maka Ho di ditolak dan Hi di terima yang berarti bahwa terdapat hubungan positif dan signifikan efikasi diri (self-efficacy) dan kompetensi profesional secara bersamasama dengan kinerja guru.

Tabel 4. Rekapitulasi Hasil Analisis Uji Koefesien Determinasi

\begin{tabular}{|c|c|c|c|c|}
\hline \multirow{2}{*}{ Koefisien Determinasi } & \multirow{2}{*}{$R^{2}$} & \multicolumn{2}{|c|}{ Pengaruh } & \multirow{2}{*}{ Keterangan } \\
\hline & & Var & Lain & \\
\hline $\mathrm{Y}$ atas $\mathrm{X}_{1}$ & 0,435 & $43,5 \%$ & $56,5 \%$ & Terdapat Pengaruh \\
\hline $\mathrm{Y} \operatorname{atas} \mathrm{X}_{2}$ & 0,435 & $43,5 \%$ & $56,5 \%$ & Terdapat Pengaruh \\
\hline$Y \operatorname{atas} X_{1} d a n X_{2}$ & 0,438 & $43,8 \%$ & $56,2 \%$ & Terdapat Pengaruh \\
\hline
\end{tabular}

Memperhatikan hasil analisis regresi sederhana kinerja guru (Y) atas efikasi diri (self-efficacy) $\left(\mathrm{X}_{1}\right)$ besarnya pengaruh ditunjukkan oleh koefisien determinasi $\mathrm{R}^{2}(R$ square $)=0,435$ yang berarti bahwa efikasi diri (self-efficacy) memberikan pengaruh dengan kinerja guru sebesar 43,5\% dan berarti sisanya 56,5\% ditentukan oleh faktor lainnya. Hasil analisis regresi sederhana kinerja guru $(\mathrm{Y})$ atas kompetensi profesional $\left(\mathrm{X}_{2}\right)$ besarnya pengaruh ditunjukkan oleh koefisien determinasi $\mathrm{R}^{2}(R$ square) $=0,435$ yang berarti bahwa kompetensi profesional memberikan hubungan dengan kinerja guru sebesar 43,5\% dan sisanya yaitu 56,5\% ditentukan oleh faktor lainnya. Hasil analisis regresi berganda, besarnya pengaruh ditunjukkan oleh koefisien determinasi $\mathrm{R}^{2}(R$ square $)=0,438$ yang berarti bahwa efikasi diri (self-efficacy) dan kompetensi profesional secara bersamaan dengan kinerja guru sebesar $43,8 \%$ dan sisanya yaitu 56,2\% ditentukan oleh faktor lainnya.

Tabel 5. Rekapitulasi Hasil Analisis Uji Koefesien Regresi

\begin{tabular}{ccccccc}
\hline Persamaan Regresi & \multicolumn{3}{c}{ Regresi } & Beta & $t$ & Sig \\
\cline { 2 - 4 } & $c$ & $X_{1}$ & $X_{2}$ & & & \\
$Y$ atas $X_{1}$ & 42,077 & 0,652 & - & .659 & 8.856 & .000 \\
$Y$ atas $X_{2}$ & 41,492 & - & 0,654 & .659 & 8.853 & .000 \\
$Y$ atas $X_{1} d a n X_{2}$ & 41,160 & 0,333 & 0,326 & - & 4.589 & .000 \\
\hline
\end{tabular}

Memperhatikan hasil analisis regresi sederhana kinerja guru (Y) atas efikasi diri (self-efficacy) $\left(\mathrm{X}_{1}\right)$, menunjukkan persamaan regresi (unstandardized coefficients B) $\hat{Y}=42,077+0,652 \mathrm{X}_{1}$ yang berarti bahwa setiap peningkatan satu unit skor efikasi diri (self-efficacy) mempengaruhi peningkatan skor kinerja guru sebesar 0,652. Hasil 
analisis regresi sederhana kinerja guru $(\mathrm{Y})$ atas kompetensi profesional $\left(\mathrm{X}_{2}\right)$ menunjukkan persamaan regresi (unstandardized coefficients $B$ ) $\hat{Y}=41,492+0,654 X_{2}$ yang berarti bahwa setiap peningkatan satu unit skor kompetensi profesional mempengaruhi peningkatan skor kinerja guru sebesar 0,654. Hasil analisis regresi berganda, menunjukkan persamaan regresi (unstandardized coefficients B) $\hat{Y}=41,160+$ $0,333 \mathbf{X}_{1}+0,326 \mathbf{X}_{2}$ yang berarti bahwa setiap peningkatan satu unit skor efikasi diri (self-efficacy) dan kompetensi profesional secara bersamasama mempengaruhi peningkatan skor kinerja guru sebesar $0,333+$ $0,326=0,659$.

\section{B. Pembahasan}

Berdasarkan pengujian hipotesis menujukkan bahwa terdapat hubungan yang positif dan signifikan antara efikasi diri (self-efficacy) dengan kinerja guru pada empat sekolah menengah atas sub rayon 11 parung yang telah ditentukan. Hal ini ditunjukan oleh kekuatan pengaruh atau koefisien korelasi sebesar 0,659 pada tingkat kepercayaan $99 \%(\alpha=0.01)$, sedangkan besarnya pengaruh atau koefisien determinasi R-square sebesar 0,435 yang berarti bahwa efikasi diri (self-efficacy) memberikan pengaruh dengan kinerja guru sebesar $43,5 \%$ dan berarti sisianya $56,5 \%$ ditentukan oleh faktor lainnya. Untuk arah pengaruh atau koefesien regresi diproleh $\hat{\mathrm{Y}}=$ $42,077+0,652 X_{1}$ yang berarti bahwa setiap peningkatan satu unit skor efikasi diri (self-efficacy) mempengaruhi peningkatan skor kinerja guru sebesar 0,652 (korelasi kuat).

Adapun berdasarkan penelitian yang telah dilakukan oleh Kreitner dan Kinicki mengatakan bahwa ada keterkaitan antara efikasi diri (self-efficacy) dengan kinerja hubungan antara efikasi diri (selfefficacy) dan kinerja adalah satu siklus. Apabila siklus semakin tinggi maka akan berhasil dalam melaksanakan satu pekerjaan, sebaliknya siklus rendah maka akan gagal dalam melaksanakan satu pekerjaan. Dari pendapat ini, dapat disimpulkan bahwa kemampuan diri sangat penting dan memiliki nilai yang sangat strategis serta berhubungan langsung dengan kinerja. Berdasarkan analisis tersebut bahwa efikasi diri (self-efficacy) merupakan salah satau faktor yang mempengaruhi kinerja guru. Peningkatan efikasi diri (self-efficacy) akan diikuti dengan peningkatan kinerja guru.

Berdasarkan pengujian hipotesis menujukkan bahwa terdapat hubungan yang positif dan signifikan antara kompetensi profesional dengan kinerja guru pada empat sekolah menengah atas sub rayon 11 
parung yang telah ditentukan. Hal ini ditunjukan oleh kekuatan pengaruh atau koefisien korelasi sebesar 0,659 pada tingkat kepercayaan 99\% $(\alpha=0.01)$, sedangkan besarnya pengaruh atau koefisien determinasi R-square sebesar 0,435 yang berarti bahwa kompetensi profesional memberikan hubungan dengan kinerja guru sebesar 43,5\% dan sisanya yaitu 56,5\% ditentukan oleh faktor lainnya. Untuk arah pengaruh atau koefesien regresi $\hat{Y}=41,492+0,654 X_{2}$ yang berarti bahwa setiap peningkatan satu unit skor kompetensi profesional mempengaruhi peningkatan skor kinerja guru sebesar 0,654 (korelasi kuat).

Penelitian terdahulu juga membuktikan bahwa Kompetensi memiliki hubungan dengan kinerja guru, sebagaimana yang dilakukan oleh Colquitt bahwa orang yang memiliki kemampuan umum kognitif lebih tinggi cenderung lebih baik dalam mempelajari sesuatu dan membuat keputusan. Kemampuan umum kognitif mempunyai hubungan positif yang kuat dengan kinerja kerja terutama disebabkan pengaruhnya pada kinerja tugas. Berdasarkan analisis tersebut bahwa kompetensi profesional merupakan salah satau faktor yang mempengaruhi kinerja guru. Peningkatan kompetensi profesional akan diikuti dengan peningkatan kinerja guru.

Hubungan kedua variabel independen (efikasi diri (self-efficacy) dan kompetensi profesional) secara simultan dengan kinerja guru menujukkan adanya hubungan yang positif dan signifikan. Jadi pada permasalahan yang sedang diteliti diketahui bahwa secara simultan kedua variabel independen atau bebas (efikasi diri (self-efficacy)) dan kompetensi profesional) memiliki hubungan yang positif dan signifikan terhadap kinerja pada empat sekolah menengah atas sub rayon 11 parung yang telah ditentukan. Hal ini dapat dilihat dari kekuatan pengaruh koefisen korelasi $=0,662$ yang berarti bahwa efikasi diri (self-efficacy) dan kompetensi profesional) secara bersamaan dengan kinerja guru. Sedangkan besarnya pengaruh koefesien determinasi Rsquare sebesar 0,438 yang berarti bahwa besarnya pengaruh efikasi diri (self-efficacy) dan kompetensi profesional secara bersamaan dengan kinerja guru sebesar 43,8\% dan sisanya yaitu 56,2\% ditentukan oleh faktor lainnya. Adapun arah pengaruh persaman regresi $\hat{Y}=41,160+$ $0,333 \mathbf{X}_{1}+0,326 \mathbf{X}_{2}$ yang berarti bahwa setiap peningkatan satu unit skor independen efikasi diri (self-efficacy) dan kompetensi profesional secara bersamaan mempengaruhi peningkatan skor kinerja guru sebesar $0,333+0,326=0,659$ (korelasi kuat). 

dengan Kinerja Guru pada...

Jika dilihat dari nilai R-square di atas maka secara bersama- sama variabel efikasi diri (self-efficacy) dan kompetensi profesional atau variabel independen memberikan kontribusi atau pengaruh terhadap kinerja guru pada sekolah menengah atas sub rayon 11 parung dan sisanya merupakan pengaruh faktor lain diluar kedua variabel bebas yang diteliti. Jadi meningkat dan menurunnya kinerja guru tidak hanya dipengaruhi oleh efikasi diri (self-efficacy) dan kompetensi profesional saja akan tetapi bisa juga dipengaruhi oleh faktor-faktor lainnya.

Beberapa penelitian terdahulu juga membuktikan bahwa efikasi diri (self-efficacy) dan Kompetensi memiliki hubungan dengan kinerja guru, sebagaimana yang dilakukan oleh Timothy yang mengemukakan bahwa kemampuan kognitif, self-efficacy, dan tujuan masing-masing mempengaruhi kinerja, meskipun hasil bervariasi tergantung pada sampel dan model yang diuji. Lebih lanjut Santrock mengemukakan bahwa self-efficacy bukanlah merupakan satu- satunya faktor yang mempunyai pengaruh kuat pada prestasi. Efikasi diri (self-efficacy) yang tinggi tidak akan menghasilkan kinerja yang kompeten bila pengetahuan dan keterampilan yang dibutuhkan kurang. Berdasarkan analisis tersebut bahwa efikasi diri (self-efficacy) dan kompetensi profesional keduanya merupakan faktor yang mempengaruhi kinerja guru. Peningkatan efikasi diri (self-efficacy) dan kompetensi profesional akan diikuti dengan peningkatan kinerja guru.

\section{Penutup}

Terdapat hubungan yang positif dan signifikan antara efikasi diri (self- efficacy) dengan kinerja guru. Terdapat hubungan yang positif dan signifikan antara efikasi diri (self-efficacy) dan kompetensi profesional dengan kinerja guru. Terdapat hubungan yang positif dan signifikan antara efikasi diri (self- efficacy) dan kompetensi profesional secara bersama- sama dengan kinerja guru pada Sekolah Menengah Atas Sub Rayon 11 Parung. Hal ini dapat dilihat dari kekuatan pengaruh koefisen korelasi dan besarnya pengaruh koefesien determinasi. Arah pengaruh persaman regresi mengindikasikan bahwa setiap peningkatan satu unit skor independen efikasi diri (self-efficacy) dan kompetensi profesional secara bersamaan mempengaruhi peningkatan skor kinerja guru.

Implikasinya adalah semakin tinggi seorang guru apabila mempunyai efikasi diri (self-efficacy) untuk menyelesaikan tugastugasnya maka semakin tinggi pula kinerja guru tersebut. Begitupun sebaliknya semakin rendah efikasi diri (self-efficacy) seorang guru 
maka semakin rendah pula kinerja guru tesebut. Seorang guru yang memiliki kemampuan tingkat lebih tinggi mampu untuk memperoleh pengetahuan lebih banyak tentang pekerjaannya dalam hal ini tugas guru yang lebih kompleks. Seorang guru yang memiliki efikasi diri (self-efficacy) tinggi akan mampu melalui tantangan dan kesulitan sehingga sanggup mempelajari sesuatu yang baru yang meningkatkan kemampuannya sehingga akan menghasilkan kinerja yang lebih baik. Artinya dalam rangka meningkatkan kinerja guru agar memperoleh hasil yang maksimal maka perlu didukung dengan efikasi diri (selfefficacy) guru yang tinggi juga peningkatan kompetensi profesional yang dimiliki guru, maka semakin baik pula kinerja guru yang ada di sekolah tersebut. Sebaliknya rendah efikasi diri (self-efficacy) seorang guru dan semakin kurang kompetensi profesional yang dimiliki guru maka semakin rendah pula kinerja guru yang ada di sekolah tersebut.

Berdasarkan hasil temuan penelitian menunjukkan adanya hubungan yang positif dan signifikan antara kompetensi profesional secara bersama- sama dengan kinerja guru pada Sekolah Menengah Atas Sub Rayon 11 Parung, maka peneliti menyarankan diperlukan adanya usaha dan upaya dari pihak lembaga dan dari pihak pimpinan, dalam rangka meningkatkan kinerja guru dengan cara mendukung dan memfasilitasi guru- guru yang ingin meningkatkan pendidikan, memberi penghargaan bagi guru- guru yang berprestasi dalam mengharumkan nama lembaga atau sekolah dan menerapkan serta meningkatkan standar penilaian kinerja guru. Pekerjaan yang dilakukan dan dihasilkan guru perlu dihargai, fasilitas yang diinginkan mencukupi, serta terdapat pengakuan terhadap prestasi kerja guru di sekolah agar guru terpuaskan dengan apa yang didapatnya di tempat kerja. Dengan demikian tentunya guru akan melaksanakan tugasnya dengan kompetensi yang mereka miliki.

Guru hendaknya meningkatkan kompetensi dirinya sebagai seorang guru terlebih lagi dalam keprofesionalannya, hal ini menjadi penunjang dirinya dalam menjalankan tugas sebagaimana mestinya sehingga pelaksanaan pembelajaran akan berjalan dengan baik dan mencapai tujuannya. Dengan adanya pengaruh yang cukup signifikan antara efikasi diri (self-efficacy) dan kompetensi profesional secara bersama- sama dengan kinerja guru, maka pimpinan sekolah harus dapat senantiasa meningkatkan kompetensi guru- gurunya dengan berbagai cara (pelatihan, seminar, kompetisi, dan lain sebagainya) dan senantisa memberi motivasi dan hal- hal yang membuat guru 
meningkatkan efikasi diri mereka menjadi lebih tinggi lagi agar kinerja terus meningkat dan bertambah.

\section{Daftar Pustaka}

Amstrong, Michael. Performance Management Key Strategies and Practical Guidelines. London: British Library, 2006.

Arikunto, Suharsimi. Prosedur Penelitian Suatu Pendekatan Praktek. Jakarta: PT Rineka Cipta, 2012.

Azwar, Saifudin. Metode Penelitian. Yogyakarta: Pustaka Pelajar, 2011.

Chalil, Achjar. Pembelajaran Berbasis Fitrah. Jakarta : PT.Balai Pustaka, 2008.

Colquitt, Jason A., Jeffrey A. Lepine dan Michael J. Wesson. Organizational Behavior Improving Performance and Commitment in Workplace. New York: McGraw-Hill, 2013.

Dewan Perwakilan Rakyat Republik Indonesia, Undang-Undang RI Nomor 20 Tahun 2003 tentang Sisdiknas. Bandung: Citra Umbara. t.th.

Gibson, James L., et al. Organization: Behavior, Structure, Processes. New York: Mc Graw-Hill, 2012.

Ivanovich, John M, Robert Konopaske dan Michael T. Matheson. Organizational Behavior and Management. New York: McGrawHill, 2014.

Mangkunegara, Anwar Prabu. Perilaku dan Budaya Organisasi. Bandung: Refika Aditama, 2012.

Priansa, Donni. Kinerja dan Profesionalisme Guru, Bandung: Alfabeta, 2014.

Robbins, Stephen P. dan Timothy A. Judge. Organizational Behavior. New Jersey: Pearson Prentice Hall, 2017.

Roqib, Moh. Ilmu Pendidikan Islam: Pengembangan Pendidikan Intergratif di Sekolah, Keluarga, Masyarakat. Jogyakarta: PT LKIS Printing cemerlang, 2009.

Samariya, Farida. Sertifikasi Guru; Apa, Mengapa, dan Bagaimana? Bandung: Yrama Widya, 2008.

Santrock, John W. Educational Psychology. New York: Mc Graw-Hill, 2011.

Schermerhorn, Jr, John R., et al. Organizational Behavior. USA: John Wiley \& Sons, Inc, 2010.. 
Soediyarto. Rekrutmen, Pendidikan dan Penempatan serta Pemahaman Guru untuk Menunjang Pendidikan untuk Masyarakat Indonesia Baru. Jakarta: Grasindo, 2012.

Sudjana, Nana. Dasar- dasar Proses Belajar Mengajar. Bandung: Sinar Baru Algensindo Offset, 1989.

Sugiyono. Metode Penelitian Kuantitatif, Kualitatif, dan $R \& D$. Bandung: Alfabet, 2010.

Supardi. Kinerja Guru. Jakarta: PT Raja Grafindo Persada, 2014.

Suprihatiningrum, Jamil. Guru Profesional Pedoman kinerja, Kualifikasi \& Kompetensi Guru. Yogyakarta: Arruz Media, 2013.

Umar, Husein. Metodologi Penelitian untuk Skripsi dan Tesis Bisnis. Jakarta: Grafindo Persada, 2008.

Woods, Stephen A, and Michael A. West. The Psychology of Work Organizations. Hamispire: Cengage Learning EMEA, 2010.

https://nasional.sindonews.com/read/1052998/15/memprihatinkan-adaguru-hanya-bisa-jawab-satu-soal-ujian-1444794753, diakses pada tanggal 01 Nopember 2017 pukul 17.51 WIB.

http://mappifhui.org/sejarah/, diakses pada tanggal 12 Agustus 2018 pukul 04.46 WIB.

Reportase Investigasi, Sekolah Ajari Aku Curang, Trans TV: Sabtu: 27 April 2013, http://www.youtube.com/watch?v=EXyDUDcDuy4. diakses pada tanggal 01 Nopember 2017 pukul 17.33 WIB.

https://news.okezone.com/read/2016/04/09/65/1358480/beragamkecurangan-un-terulang-setiap-tahun, diakses pada tanggal 01 Nopember 2017 pukul 17.43 WIB.

http://dok.joglosemar.co/baca/2015/11/17/guru-bukan-kuli.html, diakses pada tanggal 01 Nopember 2017 pukul 18.03 WIB.

http://pepnews.com/2017/11/27/guru-cabul-pelaku-kekerasan-seksualdan-hari-guru-nasional/ diakses pada tanggal 01 Nopember 2017 pukul 17.23 WIB. 